\title{
Cytotoxic and apoptosis inducing effect of some pyrano [3, 2-c] pyridine derivatives against MCF-7 breast cancer cells
}

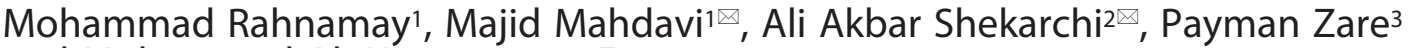 \\ and Mohammad Ali Hosseinpour Feizi ${ }^{1}$
}

1Department of Biology, Faculty of Natural Science, University of Tabriz, Tabriz, Iran; 2Public Health Departments, Khalkhal Faculty of Medical Sciences, Ardabil University of Medical Sciences, Ardabil, Iran; ${ }^{3}$ Department of Pathobiology, Faculty of Veterinary Medicine, University of Tabriz, Tabriz, Iran

Anti-cancer activities of some pyrano-pyridines have been previously reported. Herein, we investigated antiproliferative and apoptotic effects of the novel pyrano [3, 2-C] pyridine (P.P, TPM.P, 4-CP.P and 3-NP.P) compounds against MCF-7 breast cancer cells. The MCF-7 cells were cultured in the presence of various concentrations $(20-200 \mu \mathrm{M})$ of the tested compounds for 3 days and the cell viability was determined by MTT assay. Induction of apoptosis was qualitatively assayed by acridine orange/ethidium bromide ( $\mathrm{AO} / \mathrm{EtBr})$ staining, DNA fragmentation assay, as well as quantitatively by Annexin V/PI double staining and cell cycle analysis. These compounds inhibited growth and proliferation of the MCF-7 cells in a dose- and time-dependent manner. The IC50 values of P.P, TPM.P, 4-CP.P and 3-NP.P after $24 \mathrm{~h}$ of exposure were calculated to be $100 \pm 5.0,180 \pm 6.0$, $60 \pm 4.0$ and $140 \pm 5.0 \mu \mathrm{M}$, respectively. 4-CP.P was determined as the most potent compound and was chosen for further studies. The result of flow cytometric cell cycle analysis indicated an increase in sub-G1 population after $72 \mathrm{~h}$ treatment of the cells. Furthermore, this was accompanied by exposure of phosphatidylserine (PS) in the outer cell membrane after time course of treatment with the 4-CP.P. Based on these observations, the pyrano $[3,2-c]$ pyridines can be regarded as a valuable candidate for further pharmaceutical evaluations.

Keywords: apoptosis, pyrano-pyridine, breast cancer, MCF-7 cells

Received: 21 June, 2018; revised: 28 January, 2018; accepted: 01 March, 2018; available on-line: 27 August, 2018

\e-mail: majid.mahdavi@tabrizu.ac.ir; maj.mahdavi@gmail.com (MM); shekarchiaa@gmail.com (AAS)

Abbreviations: P.P, 2-amino-8-benzylidene-5,6,7,8-tetrahydro6-phenethyl-4-phenyl-4h-pyrano-[3,2,c] pyridine-3-carbonitrile; TPM.P, 2-amino-5,6,7,8-tetrahydro-6-phenethyl-4-thiophen-2-yl8-(thiophen-2-yl)methylene) 4h-pyrano-[3,2-c]pyridine-3-carbonitrile; 4-CP.P 8-(4-chlorobenzylidene)-2-amino-4-(4-chlorophenyl)5,6,7,8-tetrahydro-6-phenethyl-4h-pyrano-[3,2-c] pyridine-3-carbonitrile; 3-NP.P, 8-(3-nitrobenzylidene)-2-amino-5,6,7,8-tetrahydro4-(3-nitrophenyl)-6-phenethyl-4h-pyrano[3,2-c]pyridine-3-carbonitrile; FBS, fetal bovine serum; MTT, 3-(4, 5-dimethylthiazol-2-yl) 2, 5-diphenyl tetrazolium bromide; PBS, phosphate-buffered saline; $\mathrm{Pl}$, propidium iodide; $\mathrm{AO} / \mathrm{EtBr}$, Acridine orange /ethidium bromide

\section{INTRODUCTION}

Breast cancer is the most prevalent cancer among women and one of the main reasons of cancer deaths in women worldwide (Chen et al., 2013). More than a million persons have been diagnosed with the illness in 2008 and annually more than 200000 new cases of breast cancer are identified (Germano \& O’Driscoll, 2009). Ex- tensive research has been done in conventional therapies such as chemotherapy, surgery and radiotherapy. Even though chemotherapy has been widely respected to treat breast cancer (Huang et al., 2012), the chemotherapeutic agents like anthracyclines bring very serious side effects. Also, their effectiveness is limited due to drug resistance (Huang et al., 2010; Lage, 2003). Therefore, it is essential to develop safe and effective novel alternative agents for treatment of this disease. Previous studies have shown that some chemical compounds are excellent resources of effective agents for treatment of many diverse cancers via induction of apoptosis (Cragg \& Newman, 2005; Haefner, 2003). Apoptosis, as a physiological event, refers to programmed cell death distinguished by DNA fragmentation, cellular shrinking, chromatin accumulation and making of apoptotic bodies (Taylor et al., 2008).

Pyrano [3, 2-c] pyridines and their derivatives have been found to possess many interesting biological properties, including anti-cancer (El-Subbagh et al., 2000; Magedov et al., 2008), anti-bacterial (Hanawa et al., 2004; Kumar \& Rajendran, 2004), anti-fungal and anti-algal (Cantrell et al., 2005), anti-inflammatory and anti-malaria (Isaka et al., 2001) activities. Additionally, they have demonstrated to be effective in treatment of human cancer cells (Magedov et al., 2007).

The purpose of the research presented here was to investigate the effect of four novel compounds derived from pyrano [3, 2-c] pyridines (Fig. 1) on growth rate and viability of the MCF-7 cells. Moreover, in this cell line induction of apoptosis was also evaluated for the most active compound among those tested here.

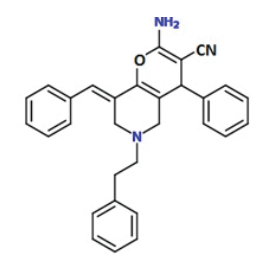

(P.P)

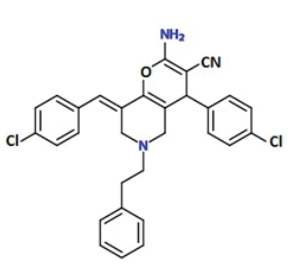

(4-CP.P)

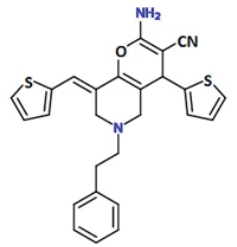

(TPM.P)

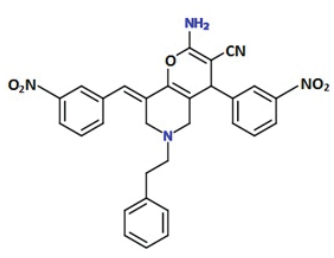

(3-NP.P)
Figure 1. Chemical structure of the investigated pyrano-pyridine compounds. 
Table 1. Effect of the new pyrano [3, 2-c] pyridine derivatives on the MCF-7 cell viability.

Cells were treated with various concentrations of the compounds for 24, 48 and 72 hrs. Cell viability was evaluated by MTT assay. Data were expressed as a percentage of control assayed in the absence of the compounds. Each point represents the mean \pm S.D. of three independent experiments $(p<0.05)$.

\begin{tabular}{|c|c|c|c|c|}
\hline \multirow{2}{*}{ Compound Name } & \multirow{2}{*}{$\begin{array}{c}\text { Concentration } \\
(\mu \mathrm{M})\end{array}$} & \multicolumn{3}{|c|}{ Viability (\% of Control) } \\
\hline & & $24 h$ & $48 \mathrm{~h}$ & $72 \mathrm{~h}$ \\
\hline P.P & $\begin{array}{c}0 \\
20 \\
40 \\
60 \\
80 \\
100 \\
120 \\
140 \\
160 \\
200\end{array}$ & $\begin{array}{c}100 \\
93 \pm 1.8 \\
88 \pm 3.7 \\
74 \pm 0.9 \\
61 \pm 1.1 \\
48 \pm 3.7 \\
36 \pm 3.1 \\
26 \pm 2.6 \\
21 \pm 0.9 \\
19 \pm 2.6\end{array}$ & $\begin{array}{c}100 \\
88 \pm 1.9 \\
75 \pm 3.2 \\
56 \pm 2.2 \\
40 \pm 2.8 \\
31 \pm 0.9 \\
22 \pm 1.9 \\
16 \pm 1.8 \\
13 \pm 3.3 \\
10 \pm 1.7\end{array}$ & $\begin{array}{c}100 \\
76 \pm 0.8 \\
54 \pm 2.8 \\
36 \pm 2.6 \\
27 \pm 1.7 \\
20 \pm 1.8 \\
13 \pm 3.4 \\
11 \pm 2.7 \\
9 \pm 1.50 \\
6 \pm 1.20\end{array}$ \\
\hline TPM.P & $\begin{array}{c}0 \\
20 \\
40 \\
60 \\
80 \\
100 \\
120 \\
140 \\
160 \\
200 \\
\end{array}$ & $\begin{array}{c}100 \\
95 \pm 2.6 \\
89 \pm 0.7 \\
83 \pm 3.5 \\
76 \pm 1.5 \\
69 \pm 1.3 \\
63 \pm 0.8 \\
59 \pm 3.3 \\
55 \pm 3.1 \\
47 \pm 2.7\end{array}$ & $\begin{array}{c}100 \\
91 \pm 0.2 \\
87 \pm 1.2 \\
81 \pm 2.2 \\
71 \pm 1.6 \\
62 \pm 1.4 \\
56 \pm 3.4 \\
51 \pm 4.1 \\
45 \pm 2.8 \\
37 \pm 3.2\end{array}$ & $\begin{array}{c}100 \\
86 \pm 2.5 \\
82 \pm 3.5 \\
71 \pm 4.2 \\
56 \pm 1.3 \\
46 \pm 1.7 \\
41 \pm 1.2 \\
33 \pm 2.1 \\
28 \pm 1.6 \\
19 \pm 3.1\end{array}$ \\
\hline 4-CP.P & $\begin{array}{c}0 \\
20 \\
40 \\
60 \\
80 \\
100\end{array}$ & $\begin{array}{c}100 \\
66 \pm 1.1 \\
56 \pm 3.9 \\
50 \pm 1.5 \\
47 \pm 2.4 \\
42 \pm 1.2\end{array}$ & $\begin{array}{c}100 \\
56 \pm 3.9 \\
50 \pm 0.5 \\
45 \pm 3.8 \\
43 \pm 0.6 \\
35 \pm 2.5\end{array}$ & $\begin{array}{c}100 \\
51 \pm 2.6 \\
39 \pm 1.7 \\
32 \pm 3.9 \\
31 \pm 0.7 \\
29 \pm 2.1\end{array}$ \\
\hline 3-NP.P & $\begin{array}{c}0 \\
20 \\
40 \\
60 \\
80 \\
100 \\
120 \\
140 \\
160 \\
200\end{array}$ & $\begin{array}{c}100 \\
92 \pm 2.4 \\
90 \pm 1.6 \\
85 \pm 3.2 \\
77 \pm 1.9 \\
69 \pm 3.9 \\
58 \pm 1.1 \\
52 \pm 3.7 \\
45 \pm 2.3 \\
38 \pm 3.1\end{array}$ & $\begin{array}{c}100 \\
89 \pm 1.2 \\
84 \pm 3.3 \\
79 \pm 1.3 \\
72 \pm 1.9 \\
62 \pm 0.9 \\
51 \pm 2.9 \\
44 \pm 0.8 \\
37 \pm 2.3 \\
25 \pm 2.4\end{array}$ & $\begin{array}{c}100 \\
82 \pm 2.0 \\
73 \pm 2.2 \\
67 \pm 2.4 \\
56 \pm 2.1 \\
47 \pm 1.6 \\
41 \pm 2.5 \\
37 \pm 3.1 \\
29 \pm 1.8 \\
18 \pm 2.3\end{array}$ \\
\hline
\end{tabular}

\section{METHODS AND MATERIALS}

Materials. Fetal bovine serum (FBS), penicillin-streptomycin and cell culture medium (RPMI-1640) were obtained from Gibco BRL Life Technologies (Paisley, Scotland). Culture plates were acquired from SPL (Korea). MTT reagent [3 0-(4, 5-dimethylthiazol-2-yl)-2, 5-diphenyl tetrazolium bromide] and dimethylsulfoxide (DMSO) were purchased from Sigma Aldrich (Germany). Annexin-V/PI (propidium iodide) staining kit was acquired from Roche Corporation (Germany). The MCF-7 cells were acquired from the Pasture Research Institute (Iran).

Preparation of the investigated 4H-pyrano [3,2-c] pyridine derivatives. 2-Amino-4-aryl-8-[(E)arylmethylidene]-5,6,7,8-4Hpyrano [3,2-c] pyridine derivatives were synthesized at a peptide chemistry research center, K. N. Toosi University of Technology. Briefly, reaction of 3, 5-bis [(E)-arylmethylidene]-tetrahydro$4(1 \mathrm{H})$-pyridinones with malononitril in aqueous media and in the presence of diammonium hydrogen phosphate $(10 \%)$ or piperidine $(10 \%)$ leads to pyranopyridines at room temperature. The structures of the target compounds, including 2-amino-8-benzylidene-5,6,7,8tetrahydro-6-phenethyl-4-phenyl-4h-pyrano-[3,2,c] pyridine-3-carbonitrile (P.P), 2-amino-5,6,7,8-tetrahydro6-phenethyl-4-thiophen-2-yl-8-(thiophen-2-yl)methylene) 4h-pyrano-[3,2-c]pyridine-3-carbonitrile (TPM.P), 8-(4-chlorobenzylidene)-2-amino-4-(4-chlorophenyl)- 5,6,7,8-tetrahydro-6-phenethyl-4h-pyrano-[3,2-c] pyridine3-carbonitrile (4-CP.P) and 8-(3-nitrobenzylidene)-2-amino-5,6,7,8-tetrahydro-4-(3-nitrophenyl)-6-phenethyl-4Hpyrano[3,2-c]pyridine-3-carbonitrile (3-NP.P) were established by IR, ${ }^{1} \mathrm{H}-\mathrm{NMR}, \mathrm{C}-\mathrm{NMR}$, as well as mass spectrometry and elemental analysis (Balalaie et al., 2013).

Cell culture conditions. MCF-7 cells were cultivated in RPMI 1640 medium enriched with 10\% FBS (V/V), $100 \mu \mathrm{g} / \mathrm{ml}$ streptomycin and $100 \mathrm{U} / \mathrm{ml}$ penicillin at $37^{\circ} \mathrm{C}$ in a humidified atmosphere of $5 \% \mathrm{CO}_{2}$ (Hassan et al., 2013).

Cytotoxicity analysis. Viability of the cells was analyzed with the MT'T colorimetric test that is able to detect viable cells via reduction of the yellow tetrazolium salt to purple formazan. Briefly, the MDF-7 cells $\left(6 \times 10^{3}\right.$ cells/well) were seeded into 96-well plates in triplicate and cultured in the course of the night. The cells were treated with various concentrations ( 20 to $200 \mu \mathrm{M})$ of the compounds for various times $(24 \mathrm{~h}, 48 \mathrm{~h}$ and $72 \mathrm{~h}$ ) and maintained in a $\mathrm{CO}_{2}$ incubator. At the end of each treatment, the medium was eliminated from the wells and a fresh medium including MTT reagent (final concentration of $0.5 \mathrm{mg} / \mathrm{mL}$ ) was added to each well. Then, the plates were maintained at $37^{\circ} \mathrm{C}$ for $4 \mathrm{~h}$. Next, the medium was eliminated from the wells and the formazan blue crystals were dissolved by adding $200 \mu \mathrm{l}$ of DMSO. Subsequently, cell viability and IC50 (a concentration causing $50 \%$ reduction in the viable cell number) was 
determined by measuring the absorbance at $570 \mathrm{~nm}$ using a microplate reader (Expert 96, Asys Hitech) (Mahdavi et al., 2011). Data was obtained from at least three separate experiments, where untreated and DMSO treated cells served as a negative and positive control, respectively.

Cellular morphology study. To confirm the phenomenon of apoptosis, acridine orange (AO) and ethidium bromide $(\mathrm{EtBr})$ double staining test was performed. Into 24-well plates, $6 \times 10^{3}$ cells/well were seeded and treated with the most active compound (4-CP.P) at indicated concentrations (IC50 value) for $72 \mathrm{~h}$. Cell morphology was assessed by a phase-contrast microscope (Zeiss, Germany) and cell death was studied morphologically by using fluorescent dyes (AO/EtBr). In brief, the cells were collected by centrifugation and resuspended in $100 \mathrm{ml}$ of cold PBS. Then, $20 \mathrm{ml}$ of staining solution (1:1) mixture of $100 \mathrm{mg} / \mathrm{ml}$ of $\mathrm{EtBr}$ and $100 \mathrm{mg} /$ $\mathrm{ml}$ of AO (Sigma Chemical Co.) was added. Afterwards, the morphology of cells was analyzed by ultraviolet fluorescence microscopy (Olympus BX41, Germany) (Czyz et al., 2008).

DNA fragmentation assay. MCF-7 cells were treated at only one dosage (at IC50 Value) of the 4-CP.P for different time intervals. The cells were collected after 48 and $72 \mathrm{~h}$, washed with PBS and then incubated in $1 \mathrm{ml}$ of lysis buffer [0.01M Tris- $\mathrm{HCl}(\mathrm{pH} 8.0), 0.1 \mathrm{M} \mathrm{NaCl}$, $0.025 \mathrm{M}$ EDTA ( $\mathrm{pH} 8.0$ ), and $1 \%$ SDS] which contained $10 \mu \mathrm{g} / \mathrm{mL}$ of RNase A, for $1 \mathrm{~h}$ at $37^{\circ} \mathrm{C}$, followed by treatment with $0.2 \mathrm{mg} / \mathrm{mL}$ proteinase $\mathrm{K}$ for $2 \mathrm{~h}$ at $50^{\circ} \mathrm{C}$. After centrifugation at $12000 \times g$, the DNA was extracted with phenol/chloroform/isoamyl alcohol (25:24:1) to eliminate the lipids and proteins. Then, DNA in the supernatant was precipitated overnight in ethanol at $20^{\circ} \mathrm{C}$ and pelleted at $15000 \times g$. The sample of dry pellets were resuspended in TE buffer (10 mM Tris-HCI, $\mathrm{pH} 7.9,1$ $\mathrm{mM}$ EDTA) and loaded onto a $2 \%$ agarose gel containing ethidium bromide, and then electrophoresed for $2 \mathrm{~h}$ (Aryapour et al., 2012).

Cell cycle analysis. Cells $\left(1 \times 10^{6}\right)$ were seeded in 24 well plates and following $24 \mathrm{~h}$ incubation were treated with the active compound (4-CP.P) for $72 \mathrm{~h}$. Then, the cells were detached by employing a trypsin-EDTA solution at $37^{\circ} \mathrm{C}$ for $5 \mathrm{~min}$. Afterwards, the trypsin activity was stopped by adding 10\% FBS-RPMI 1640 medium. Then, the cells were collected, placed in a microtube and centrifuged at $1000 \mathrm{rpm}$ for $5 \mathrm{~min}$. Next, the cells were washed with PBS buffer and centrifuged at $1000 \mathrm{rpm}$ for $5 \mathrm{~min}$. Subsequently, they were fixed in cold $70 \%$ ethanol, incubated for $30 \mathrm{~min}$ at $4^{\circ} \mathrm{C}$. Then, the cells were resuspended in $1 \mathrm{ml}$ of PBS, treated with ribonuclease $(50 \mu \mathrm{l}$ of a $100 \mu \mathrm{g} / \mathrm{ml}$ stock of RNase) for $30 \mathrm{~min}$ at $37^{\circ} \mathrm{C}$ and $200 \mu \mathrm{l}$ of PI (from $50 \mu \mathrm{g} / \mathrm{ml}$ stock solution) were added. The percentage of cells calculated to be in the sub-G1, G0/G1, S, and G2/M phases was analyzed by flow cytometry (BD FACSCalibur flow cytometer, USA) (Hu et al., 2002).

Apoptotic cell quantification by flow cytometry. The cells undergoing apoptosis were identified by binding of the annexin $\mathrm{V}$ protein to the exposed phosphatidylserine (PS) residues at cell surface (Riccardi \& Nicoletti, 2006). In this assay, an annexin V-FITC/ propidium iodide (PI) double staining method was used according to the manufacturer's protocol. Briefly, after double washing of the treated and untreated cells with PBS, $1 \times 10^{6}$ cells were resuspended in binding buffer $(10 \mathrm{mM}$ HEPES/NaOH, pH 7.4, $\left.140 \mathrm{mM} \mathrm{NaCl}, 2.5 \mathrm{mM} \mathrm{CaCl}_{2}\right)$. Then, $5 \mu \mathrm{l}$ of annexin V-FITC and $5 \mu \mathrm{l}$ PI were added. The mixture was incubated for $15 \mathrm{~min}$ in the dark at

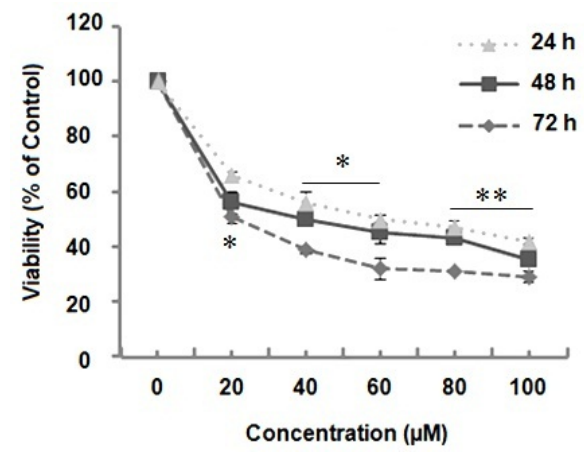

Figure 2. Anti-proliferative effects of 4-CP.P on the MCF-7 cells. The cells were treated with different concentrations $(20-100 \mu \mathrm{M})$ of 4-CP.P for 24-72 h. Cell viability was evaluated by MTT assay. Results are mean values \pm S.D. of three independent experiments. $\left({ }^{*} p<0.05,{ }^{* *} p<0.01\right)$.

room temperature and then analyzed by flow cytometry (BD FACSCalibur flow cytometer, USA) with emission filters of $515-545 \mathrm{~nm}$ for FITC (green) and $600 \mathrm{~nm}$ for PI (red). A total of 10000 cells per sample were acquired, and the data were analyzed with Cell Quest software (Becton Dickinson, San Jose, USA) (Saadat et al., 2015).

Statistical assessment. Data are presented as the mean \pm S.D. of three separate experiments and were statistically analyzed using Student T-test with Excel software. Comparison between groups was also confirmed by one-way analysis of variance (ANOVA) followed by a specific post-hoc test to analyze the difference. Differences were considered significant at $p<0.05$.

\section{RESULTS}

Previous studies showed that some pyrano [3, 2-c] pyridone derivatives have inhibitory effects on growth of different cancer cell lines (Magedov et al., 2007; Magedov et al., 2008). In this study, we examined inhibition of the MCF-7 cells proliferation of the novel pyrano [3, $2-c]$ pyridines. These compounds inhibited the growth of MCF-7 cells in a time and dose dependent manner (Table 1). As shown in Table 1, after $24 \mathrm{~h}$ exposure of the cells, the IC50 values for P.P, TPM.P, 4-CP.P and 3 -NP.P were calculated to be $100 \pm 5.0,180 \pm 6.0,60 \pm 4.0$ and $140 \pm 5.0 \mu \mathrm{M}$, respectively. 4-CP.P with the IC50 values of $60 \mu \mathrm{M}, 40 \mu \mathrm{M}$ and $20 \mu \mathrm{M}$ for $24 \mathrm{~h}, 48 \mathrm{~h}$ and $72 \mathrm{~h}$ respectively, was the most active compound against MCF-7 cells (Fig. 2, Table 2). Based on these data, we selected 4-CP.P with IC50 value of $60 \mu \mathrm{M}$ (at $24 \mathrm{~h}$ ) for further studies.

Under a phase-contrast microscope, the control cells were observed in a completely crowded and attached Table 2. The IC50 values of the investigated compounds after 24-72 h.

4-CP.P was more active in comparison with other compounds, and the IC50 value of this compound for MCF-7 cells was calculated to be $60 \pm 4.0,40 \pm 7.0$ and $20 \pm 3.0 \mu \mathrm{M}$ after 24,48 and $72 \mathrm{hrs}$, respectively. Each value represents the average of triplicate measurements \pm S.D.

\begin{tabular}{lccc}
\hline Compound & \multicolumn{3}{c}{$\mathrm{IC50}(\mu \mathrm{M})$} \\
\hline & $24 \mathrm{~h}$ & $48 \mathrm{~h}$ & $72 \mathrm{~h}$ \\
\hline P.P & $100 \pm 5.0$ & $70 \pm 3.0$ & $40 \pm 4.0$ \\
\hdashline TPM.P & $180 \pm 6.0$ & $140 \pm 4.0$ & $90 \pm 3.0$ \\
\hdashline $4-C P . P$ & $60 \pm 4.0$ & $40 \pm 7.0$ & $20 \pm 3.0$ \\
\hdashline 3-NP.P & $140 \pm 5.0$ & $120 \pm 6.0$ & $100 \pm 5.0$ \\
\hline
\end{tabular}



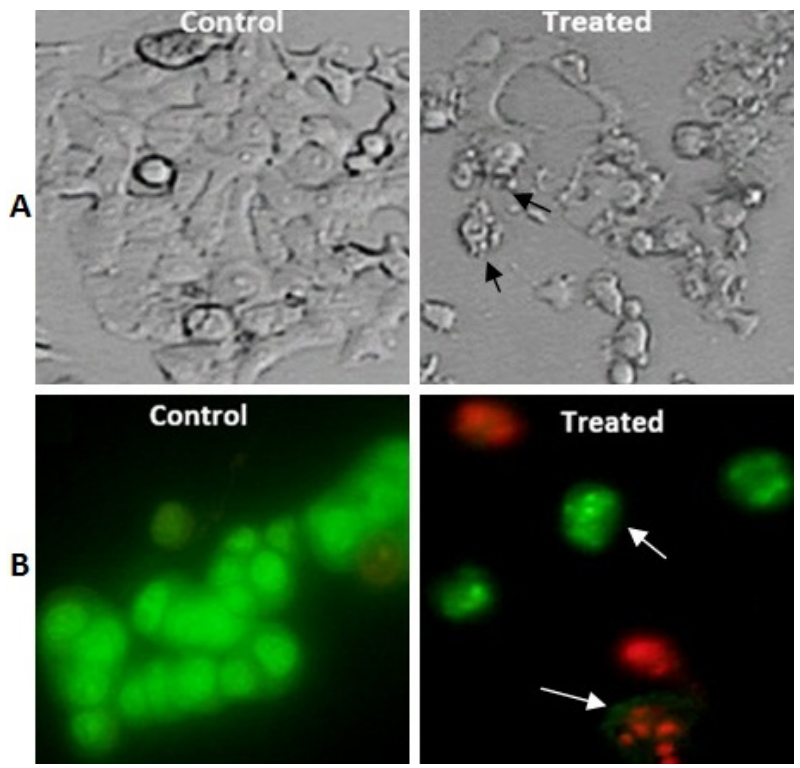

Figure 3. Phase-contrast and fluorescence microscopic observation of the MCF-7 cells treated with 4-CP.P (at IC50 value) for $72 \mathrm{~h}$.

(A) Phase-contrast image of the MCF-7 cells. The control cells have completely crowded and attached, while the treated cells obviously have been detached, condensed and fragmented. (B) fluorescence microscopy evaluation of the treated and untreated cells after AO/EB staining. The control cells had large and round nucleus, without any condensation or fragmentation of the chromatin, whereas the cells treated with 4-CP.P showed high percentages of cell shrinkage, chromatin fragmentation, and apoptotic bodies, a typical morphological feature of apoptosis. Apoptotic bodies are indicated by arrows. Magnification was 200x.

form to the culture plate, while the treated cells obviously were condensed, fragmented and then detached from the culture plate (Fig. 3A). To evaluate apoptosis, the MCF-7 cells were treated with the indicated concentration (IC50 values) of 4-CP.P. Then, the morphology changes were inspected by $\mathrm{AO} / \mathrm{EtBr}$ dual staining. The

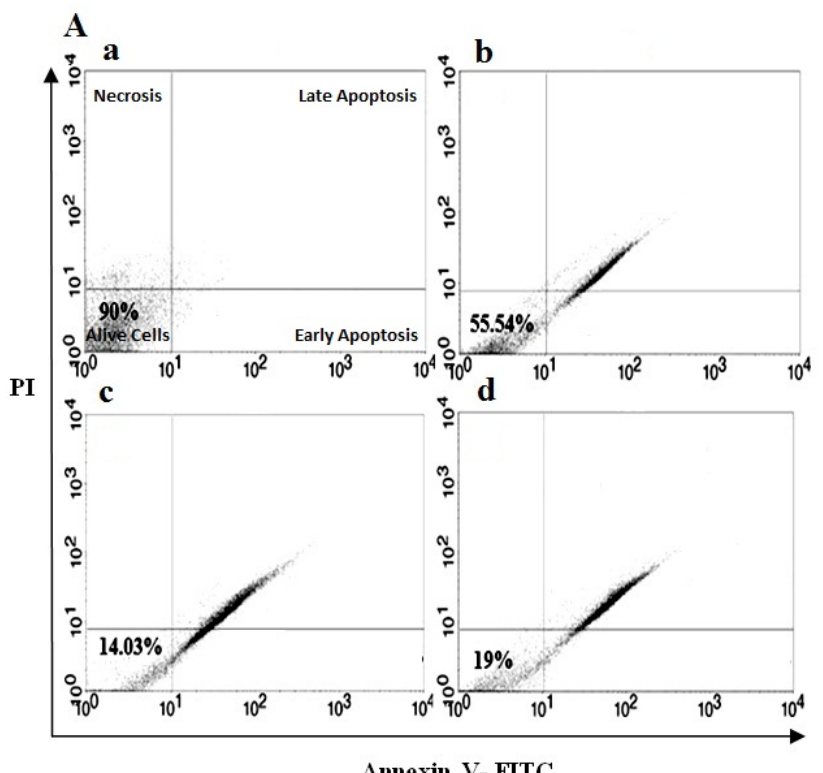

A

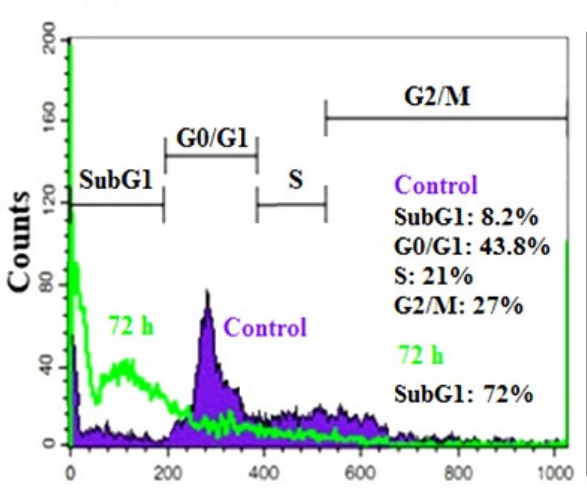

M $\quad$ C $72 \mathrm{~h}$

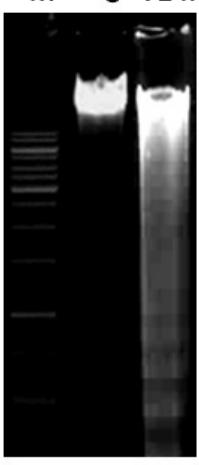

Figure 4. Effect of 4-CP.P on cell cycle phase distribution of the MCF-7 cells.

(A) Representative histograms of DNA content in the cells treated with 4-CP.P $(60 \mu \mathrm{M})$ for $72 \mathrm{~h}$. Horizontal and vertical axes indicate the relative nuclear DNA content and number of cells, respectively. Percentage of the sub-G1 phase cells was increased in the treated cells after $72 \mathrm{~h}$ of treatment as compared to untreated control. Significant difference from the control at the same phase is indicated as $p<0.05$. (B) The DNA fragmentation analysis following treatment of the MCF-7 cells with 4-CP.P. C, control cells; M, DNA Marker; $72 \mathrm{~h}$, cells treated with $60 \mu \mathrm{M}$ of 4-CP.P for $72 \mathrm{~h}$.

results revealed that the 4-CP.P is an apoptosis inducing agent in the MCF-7 cells (Fig. 3B). The images taken under fluorescence microscope showed that the control cells had large and round nucleus without any condensation or fragmentation of the chromatin. However, cell shrinkage, nucleus condensation, chromatin fragmentation, as well as formation of apoptotic bodies as a typical morphological feature of apoptosis, have been observed $72 \mathrm{~h}$ after treatment of the cells with $60 \mu \mathrm{M}$ 4-CP.P (Fig. 3B). DNA fragmentation assay was performed with agarose gel electrophoresis to confirm morphological changes in the 4-CP.P treated cells (Fig. 4B).

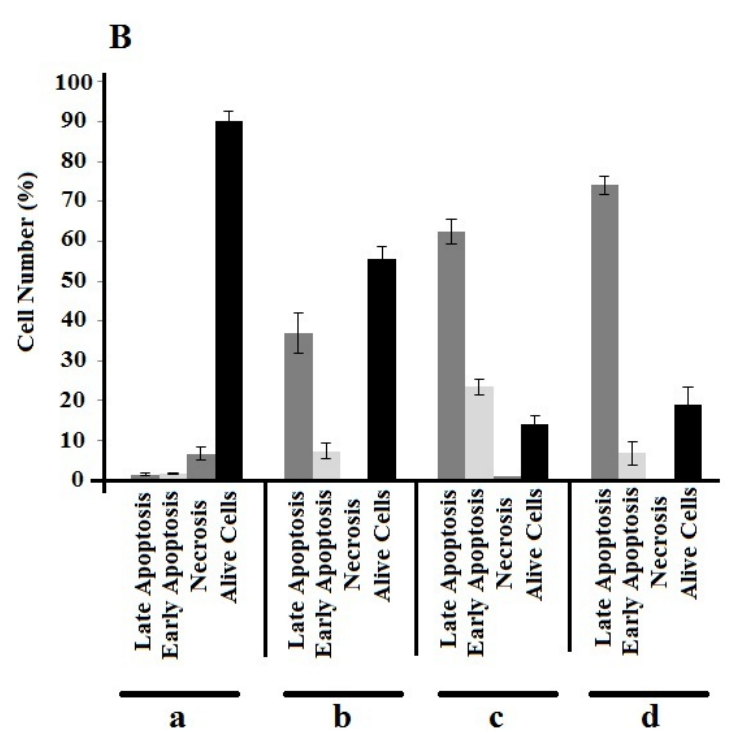

Figure 5. Quantitative analysis of apoptotic cells induced by 4-CP.P using annexin V/PI double staining assay.

(A) Representative flow cytometry results of the apoptotic cells after $24-72 \mathrm{~h}$ treatment. (a) Untreated cells, (b) cells treated for $24 \mathrm{~h}$, (c) cells treated for $48 \mathrm{~h}$, (d) cells treated for $72 \mathrm{~h}$. As is evident from the figure, a shift was accreted to late apoptosis or necrosis (upperright quadrant panel), as compared to control. (B) The percentage of live, necrotic, early apoptotic and late apoptotic cells. The results are expressed as mean \pm S.D. of three independent experiments. $p<0.05$. 
The data revealed that the 4-CP.P induces apoptosis in the MCF-7 cells.

In order to gain an insight into the mode of cell death mechanism by 4-CP.P, the cell cycle phase distribution was analyzed by means of Fluorescence Activated Cell Sorting (FACS) flow cytometer. The FACS data described the effect of indicated concentration of 4-CP.P $(60 \mu \mathrm{M})$ on cell cycle phase distribution of DNA. Our results demonstrated that the DNA content of sub G1 phase cells was increased in the treated cells after $72 \mathrm{~h}$ of treatment as compared to the untreated cells. According to our data, the proportion of the cells in the subG1 phase of control cells was observed at $8.2 \%$, while sub-G1 apoptotic cell percentage increased to $72 \%$ after $72 \mathrm{~h}$ treatment (Fig. 4A). These findings suggested that 4-CP.P induces sub-G1 cell cycle arrest and induction of apoptosis in MCF-7 cells.

Our previous data showed that 4-CP.P induced apoptosis in the MCF-7 cells. To confirm the previous results, the percentage of apoptotic cells was assessed by annexin V-FITC/PI staining (Fig. 5). We investigated redistribution of the plasma membrane of the cells (as a hallmark of apoptosis) to visible phosphatidyl serine after double staining with annexin-V/PI. In this assay, the MCF-7 cells that were single-positive stained with annexin V-FITC were considered as mostly early apoptotic cells, and the cells that were single positive stained with PI were considered as mostly necrotic cells, while the cells that were double-positive stained could be either necrotic or late apoptotic cells. The results indicated that after 24, 48 and $72 \mathrm{~h}$ treatment of the cells with 4-CP.P (at IC50 value), the percentage of apoptotic cells was $37 \%, 62 \%$ and $74 \%$, respectively (Fig. 5). These data showed that 4-CP.P could effectively induce apoptosis in MCF-7 cells in a time- dependent manner.

\section{DISCUSSION}

Breast cancer is a heterogeneous disease in which certain cells in the breast become abnormal and multiply uncontrollably to form a tumor (Kravchenko et al., 2011).

This disease is often (but not always) caused by a type of carcinoma called adenocarcinoma which originates in the glandular tissue. The MCF-7 cells are human breast cancer cells that are used widely for studies of tumor biology (Holliday \& Speirs, 2011). Many synthetic chemical compounds have been used to treat the MCF-7 human breast cancer. The study presented here was carried out to evaluate the cytotoxic potential of the novel pyranopyridine derivatives on the MCF-7 cell line. Furthermore, the most active compound was chosen and used for further experiments such as: DNA fragmentation assay, cell cycle analysis and annexin V/PI double staining assay. These derivatives have been reported to be cytotoxic for several types of cancer cells (Magedov et al., 2007). For example, cytotoxic activity of the several thieno [2, 3-b] pyridine derivatives against MCF-7 and HepG-2 cell lines has been reported (Hassan et al., 2013). In another study, cytotoxic activity of several 1,4-dihydropyridine (DHP) compounds containing nitroimidazole moiety at the $\mathrm{C} 4$ position were evaluated against four different cancer cell lines (Magedov et al., 2007). Our compounds were developed by substituting different groups, such as phenyl (P.P), thiophene (TPM.P), 4-chlorophenyl (4-CP.P) and 3-nitrophenyl (3-NP.P) at the 4-position of the phenyl ring (Table 1). Substitution of the 4-chloro phenyl ring (4-CP.P) with phenyl, thiophene, and also 3-nitrophenyl groups, increases its activity which suggests the presence of an electron-withdrawing group $(\mathrm{Cl})$ at the 4-position, but not at the 3-position $\left(\mathrm{NO}_{2}\right)$ of phenyl, will lead to a remarkable increase in the cytotoxic effects of these compounds. However, presence of another electronwithdrawing group, such as $\mathrm{NO}_{2}$ (3-NP.P) at the 3-position, reduces the activity of the compound (Table 1 and Table 2). This suggests that electron-withdrawing groups at the 4-position of the phenyl ring can be effective for increasing the cytotoxic activity of the tested compounds. Over all, the 3-nitro (3-NP.P) and other analogues (P.P, TPM.P) were significantly less potent than 4-CP.P (Table 1). In addition, it was observed that the most active derivative (4-CP.P) could inhibit cell viability and proliferation through promotion of apoptosis. 4-CP.P caused a reduction in cell viability in a dose and time dependent manner (Table 1, Fig. 2). AO/EtBr staining (Fig. 3B), sub-G1 cell cycle arrest (Fig. 4A) and annexin V/PI double staining (Fig. 5) revealed that the treated cells undergo apoptosis. Cell cycle analysis revealed that the decrease in proliferation was associated with the subG1 phase arrest (Fig. 4A). Indeed, the increase in the population of sub-G1 cells was accompanied with a decrease in G0/G1, S and G2/M cells after $72 \mathrm{~h}$. In parallel to the sub-G1 cell cycle arrest, apoptosis induction was observed in the MCF-7 cells after 4-CP.P treatment (Fig. 4B, 5). These data suggested that the breakdown of DNA that resulted in cell killing could be due to the cell cycle arrest and apoptosis induction (Rahimi et al., 2015; Dehkordi et al., 2015). These findings correspond with recent studies that showed the cytotoxicity and apoptosis inducing effects of different types of pyrano-pyridines on various types of cancer cells, such as human liver cancer cells, human cervical cancer cells and Human Tcell leukemia cells (Magedov et al., 2007; Magedov et al., 2008; Hassan et al., 2013).

In summary, our study demonstrated that the novel derivatives of pyrano-pyridines exhibit an anti-proliferative effect on the human breast cancer MCF-7 cells. According to our data, it was shown that 4-CP.P is the most active compound in comparison with the other compounds. This compound inhibited proliferation of the MCF-7 cells and was associated with induction of apoptosis. Overall, this compound (4-CP.P) can be regarded as a valuable candidate for further pharmaceutical evaluations. However, further experiments are needed to improve anti-proliferative properties of these compounds in the future.

\section{Conflict of interest}

The authors declare no conflicts of interest. The authors alone are responsible for the content and writing of this article.

\section{Acknowledgement}

The authors appreciate support of this investigation by the research council of University of Tabriz, Tabriz, Iran. We would also like to thank Dr. Saeed Balalaie for providing the pyrano-pyridine compounds.

\section{REFERENCES}

Aryapour H, Mahdavi M, Mohebbi SR, Zali MR, Foroumadi A (2012) Anti-proliferative and apoptotic effects of the derivatives from 4-aryl-4H-chromene family on human leukemia K562 cells. Arch Pharmacal Res 35: 1573-1582. https://doi.org/10.1007/s12272-0120908-y

Balalaie S, Mehrazar M, Haghighatnia Y (2013) Efficient synthesis of 2-amino-4-aryl-8-[(E)-arylmethylidene $]-5,6,7,8-4 \mathrm{H}$ pyrano $[3,2$-c $]$ 
pyridine in green media. Green Chem Lett Rev 6: 101-105. https:// doi.org/10.1080/17518253.2012.709280

Cantrell C, Schrader K, Mamonov L, Sitpaeva G, Kustova T, Dunbar C, Wedge D (2005) Isolation and identification of antifungal and antialgal alkaloids from Haplophyllum sieversii. J Agr Food Chemi 53: 7741-7748. https://doi.org/10.1021/jf051478v

Chen L, Chen J, Xu H (2013) Sasanquasaponin from Camellia oleifera Abel. induces cell cycle arrest and apoptosis in human breast cancer MCF-7 cells. Fitoterapia 84: 123-129. https://doi.org/10.1016/j. fitote.2012.11.009

Cragg GM, Newman DJ (2005) Plants as a source of anti-cancer agents. J Ethnopharmacol 100: 72-79. https://doi.org/10.1016/j. jep.2005.05.011

Czyz M, Jakubowska J, Sztiller-Sikorska M (2008) STI571/doxorubicin concentration-dependent switch for diverse caspase actions in CML cell line K562. Biochem Pharmacol 75: 1761-1773. https://doi. org/10.1016/j.bcp.2008.02.004

Dehkordi MF, Dehghan G, Mahdavi M, Hosseinpour Feizi MA (2015) Multispectral studies of DNA binding, antioxidant and cytotoxic activities of a new pyranochromene derivative. Spectrochimica Acta Part A: Mol Biomol Spectr 145: 353-359. https://doi.org/10.1016/j. saa.2015.03.026

El-Subbagh HI, Abu-Zaid SM, Mahran MA, Badria FA, Al-Obaid AM (2000) Synthesis and biological evaluation of certain $\alpha$, $\beta$-unsaturated ketones and their corresponding fused pyridines as antiviral and cytotoxic agents. Journal of medicinal chemistry 43: 2915-2921. https:// doi.org/10.1021/jm000038m

Germano S, O’Driscoll L (2009) Breast cancer: understanding sensitivity and resistance to chemotherapy and targeted therapies to aid in personalised medicine. Curr Cancer Drug Targets 9: 398-418. https:// doi.org/10.2174/156800909788166529

Haefner B (2003) Drugs from the deep: marine natural products as drug candidates. Drug Discovery Today 8: 536-544. https://doi. org/10.1016/S1359-6446(03)02713-2

Hanawa F, Fokialakis N, Skaltsounis A-L (2004) Photo-activated DNA binding and antimicrobial activities of furoquinoline and pyranoquinolone alkaloids from rutaceae. Planta Medica 70: 531-535. https:// doi.org/10.1055/s-2004-827153

Hassan A, Sarg M, Said M, El-Sebaey S (2013) Utility of thieno [2, 3-b] pyridine derivatives in the synthesis of some condensed heterocyclic compounds with expected biological activity. Universal Organic Chem 1: 2. https://doi.org/10.7243/2053-7670-1-2

Holliday DL, Speirs V (2011) Choosing the right cell line for breast cancer research. Breast Cancer Res 13: 215. https://doi.org/10.1186/ bcr2889

Hu H, Ahn NS, Yang X, Lee YS, Kang KS (2002) Ganoderma lucidum extract induces cell cycle arrest and apoptosis in MCF-7 human breast cancer cell. Int J Cancer 102: 250-253. https://doi. org/10.1002/ijc.10707

Huang K, Huang Y, Diao Y (2012) Wogonin induces apoptosis and down-regulates survivin in human breast cancer MCF-7 cells by modulating PI3K-AKT pathway. Int Immunopharmacol 12: 334-341. https://doi.org/10.1016/j.intimp.2011.12.004
Huang W-J, Wu C-L, Lin C-W, Chi L-L, Chen P-Y, Chiu C-J, Huang C-Y, Chen C-N (2010) Marchantin A, a cyclic bis (bibenzyl ether), isolated from the liverwort Marchantia emarginata subsp. tosana induces apoptosis in human MCF-7 breast cancer cells. Cancer Lett 291: 108-119. https://doi.org/10.1016/j.canlet.2009.10.006

Isaka M, Tanticharoen M, Kongsaeree P, Thebtaranonth Y (2001) Structures of Cordypyridones AD, Antimalarial N-Hydroxy-and NMethoxy-2-pyridones from the Insect Pathogenic Fungus Cordyceps n ipponica. J Organic Chem 66: 4803-4808. https://doi.org/10.1021/ jo0100906

Kravchenko J, Akushevich I, Seewaldt VL, Abernethy AP, Lyerly HK (2011) Breast cancer as heterogeneous disease: contributing factors and carcinogenesis mechanisms. Breast Cancer Res Treatment 128: 483493. https://doi.org/10.1007/s10549-011-1347-z

Kumar NV, Rajendran S (2004) One-pot synthesis and the biological activities of 4-methylpyrano $[3,2-\mathrm{C}]$-quinolin-2, 5-[6H]-diones. Asian J Chem 16: 1911-1914

Lage H (2003) Drug resistance in breast cancer. Cancer Therapy 1: 81-91

Magedov IV, Manpadi M, Evdokimov NM, Elias EM, Rozhkova E, Ogasawara MA, Bettale JD, Przheval'skii NM, Rogelj S, Kornienko A (2007) Antiproliferative and apoptosis inducing properties of pyrano [3, 2-c] pyridones accessible by a one-step multicomponent synthesis. Bioorg Med Chem Lett 17: 3872-3876. https://doi. org/10.1016/j.bmcl.2007.05.004

Magedov IV, Manpadi M, Ogasawara MA, Dhawan AS, Rogelj S, Van Slambrouck S, Steelant WF, Evdokimov NM, Uglinskii PY, Elias EM (2008) Structural simplification of bioactive natural products with multicomponent synthesis. 2. Antiproliferative and antitubulin activities of pyrano $[3,2-c]$ pyridones and pyrano $[3,2-c]$ quinolones. J Med Chem 51: 2561-2570. https://doi.org/10.1021/jm701499n

Mahdavi M, Davoodi J, Zali MR, Foroumadi A (2011) Concomitant activation of caspase-9 and down-regulation of IAP proteins as a mechanism of apoptotic death in HepG2, T47D and HCT-116 cells upon exposure to a derivative from 4-aryl-4H-chromenes family. Biomed Pharmacotherapy 65: 175-182. https://doi.org/10.1016/j.biopha.2011.03.001

Rahimi R, Mahdavi M, Pejman S, Zare P, Balalaei S (2015) Inhibition of cell proliferation and induction of apoptosis in K562 human leukemia cells by the derivative (3-NpC) from dihydropyranochromenes family. Acta Biochim Pol 62: 83-88. https://doi. org/10.18388/abp.2014_825

Riccardi C, Nicoletti I (2006) Analysis of apoptosis by propidium iodide staining and flow cytometry. Nature Protocols 1: 1458-1461. https://doi.org/10.1038/nprot.2006.238

Saadat YR, Saeidi N, Vahed SZ, Barzegari A, Barar J (2015) An update to DNA ladder assay for apoptosis detection. Biolmpacts: BI 5: 25-28. https://doi.org/10.15171/bi.2015.01

Taylor RC, Cullen SP, Martin SJ (2008) Apoptosis: controlled demolition at the cellular level. Nat Rev Mol Cell Biol 9: 231-241. https:// doi.org/ 10.1038/nrm2312 